NBER WORKING PAPER SERIES

ORGANIZED LABOR AND THE SCOPE OF

INTERNATIONAL SPECIALIZATION

Robert W. Staiger

Working Paper No. 2514

NATIONAL BUREAU OF ECONOMIC RESEARCH

1050 Massachusetts Avenue

Cambridge, MA 02138

February 1988

The research reported here is part of the NBER's research program in International Studies. Any opinions expressed are those of the author and not those of the National Bureau of Economic Research. 
NBER Working Paper \#2514

February 1988

\title{
Organized Labor and the Scope of International Specialization
}

\begin{abstract}
Th1s paper examines the interaction between union wages and the international pattern of production and trade. If union goods are heterogeneous in labor intensity, the introduction of an active union in the domestic country causes only the Least labor-1ntensive range of union goods to be produced there, with goods of greatest labor intensity produced abroad due to the relatively high cost of domestio union Iabor: A narrowing of the scope of domestio union production w1II eliminate relatively labor-intensive goods, leading a rent-maximizing union to ralse 1ts union premium. The 1mplications of this union behavior for comparative statios results are considered.
\end{abstract}

Robert W. Staiger Department of Economics Stanford University Stanford, CA 94305 


\section{Introduction}

Generai equilibrium analysis of labor unions has taken place primarliy within the context of closed- or smail-open-economy versions of the two-sector neoclassical model. The eariy contributions to this Iterature introduce an exogenous union wage premlum in one sector and consider the implications for various properties of the general equilibrium. I' Several recent papers have made endogenous the actions of the labor union in an effort to understand both the way unions respond to changing international conditions and the lmplications of union behavior for broader comparative statics results. 2 f What has not been considered formaliy is the effect of union activity on the internationat location of production and the pattern of international trade: that is, the simultaneous determination of the union wage and the set of products produced by union workers.

By modeling the union as operating in an import-competing sector that produces a varlety of heterogeneous goods, this paper explores the union's impact on the pattern of trade and, at the same time, the effect on union wages of shifting international patterns of production... In particular, if goods within the union sector differ in the intensity with which they require union labor, and if the (domestic) union wage premium 19 an important source of International cost differences, then oniy the least labor-intensive range of union-sector goods wili be produced domesticaliy, with goods of greatest labor intensity being produced abroad as a result of the relatively high cost of domestic union labor. With goods arranged in order of increasing labor 
Intens1ty, the 1dentity of the "marginal" good--the good of highest labor intensity that is produced in the domestic union sector--wil be determined by the size of the domestic union wage premium: it defines the scope of domestic production in the union sector, and hence the range of domestic export goods, as a function of union behavior. However, the scope of domestic union-sector production w111 itself affect the sectoral labor intensity of production, on which the wage premium of a rent-maximizing union depends. $\underline{3}^{\prime}$ As such, when a union supplies labor for the production of heterogeneous goods, the union wage premium and the pattern of international trade w111 be determined simultaneousiy.

The key ingredients of the formal model developed below to explore the link between trade patterns and union behavior are that countries differ only with respect to their degree of union activity, that goods produced with union labor are heterogeneous in the intensity with which their production requires union labor, and that there $1 \mathrm{~s}$ a single labor union setting a uniform wage across goods of the "union sector." The first assumption is extreme, but represents a modeling technique that has proved useful in highlighting the contributions of such determinants as endowments and technology to the pattern of international trade. The second assumption approximates an industry-wide union, such as the Un1ted Auto Workers or the Un1ted Steel Workers, whose members produce a variety of products. Finaliy, the assumption of a single union is made to keep the model simple. Extending the model to 1nclude many unions operating within the union sector 19 discussed in a footnote. 
The particular framework upon which the analysis rests is a variant of the two-country continuum-of-goods Rleardian model of Dornbusch, F1scher, and Samueison (1977), and is simliar in some respects to the model developed in DIxit and Grossman (1982). There are two final-goods sectors and $a$ non-traded intermediate good sector. In the union sector, firms combine unionized labor and the intermediate good in different proportions to produce the various goods of the sector. For concreteness, this sector might be thought of as the automobile Industry, the union as the UAW, and the various goods within the sector as the array of different models produced. The goods in the non-union sector are produced with combinations of non-union labor and the intermediate good and can, without loss of generaity, be aggregated into one non-union good. The 1ntermediate good is non-traded and is produced in the intermediate good sector with non-union labor alone. To neutral1ze any R1cardian basis for international trade, technologica: differences between countries that would lead to comparative advantage are assumed to be absent : only the operation of a labor union in the domestic country distingulshes it from the forelgn country. Finaliy, the domestic labor union is assumed to organize workers in the domestio union sector and to choose a single rent-maximizing wage at which its members w1iz be hired to produce the heterogeneous goods of the sector. The relationship between the union wage premlum and the pattern of production and trade that emerges fron this model has lmportant implications for the model's comparative statios results. Since the aggregate labor intensity of the domestic union sector 1 s increasing in 
the scope of domestic production, the wage premium of a rent-maximizing doemstic labor union will rise in response to increased "Intensity" of forelgn competition. Consequently, the scope of domestic production takes on a signifloance of 1 ts own, and the effects of labor migration, demand shifts, and technological change wili be altered according to their respective impacts on domestic production. In this way, union activity can aiter in a systematio way the standard comparative statics results familiar from competitive Ricardian trade theory.

The remainder of the paper proceeds as follows. After developing the model in section II, section III lilustrates the effect of an active union on comparative statics results of the Rlcardian model by considering the union response to a decilne in demand for union products, to a policy of directing R\&D efforts into the union sector, and to international labor migration. Section IV concludes.

\section{The Model}

The continuum-of-goods Ricardian model of Dornbusch, Fischer, and Samuelson (1977) ylelds strong comparative statics results concerning the effects of changes in technology, tastes, and national rabor endowments on the terms of trade, relative and real wages, and the scope of production in each of the two countries of the model. A convenient graphical representation of the model is developed by the authors to provide a simple and intultive method for determining the equilibrium and generating comparative statics results. The purpose of this section is to develop a pair of diagrams which together characterlze the 
world trade equlibrium in the presence of a rent-maximizing zabor union In the domestio country. Th1s 13 accomplished in two steps. First, the model is solved given an exogenous union wage premium. Then union behavior is explicitiy considered, and the general equilibrium of the modei is obtalned.

\section{Union Wage Premium Exogenous}

Located in each of the two countries of the model are two final goods sectors and an intermediate good sector. The intermediate good, whlch w1Il be called "capttal" and whlor is nontraded by assumption, is used as an input 1nto the production of final goods, and is produced with non-union labor alone according to a I1near homogenous technology common to both countries. Define units of the capital good so that one unit of labor produces one unit of capital in elther country. Let $r$ and $w$, respectively, be the price of the capital good and the wage of non-union labor at home, and define $r^{*}$ and $w^{*}$ similariy abroad, all measured in any common unft. Then perfect competition w112 ensure that

$$
r=w_{i} r^{*}=w^{*}
$$

as Iong as the capltal good is produced in both countries.

The two traded-goods sectors empioy labor and capital to produce Inal goods for consumption. Consider first the domestic economy. Goods of the non-union sector are produced with combinations of nonunion labor and capltal according to 1 near homogenous technologies. Since the relative price of factors used in this sector is flued by (1), competition keeps the relative prices of goods produced in the non-union 
sector fixed as well. Under the assumption that subutility over the non-union goods is homothetic, a composite non-union good can be defined whose production requires inputs of capital and non-union labor in fixed proportions. This composite non-union good will be calied good 2 .

The union sector contains a continuum of goods indexed by $z \in[0,1]$ and produced under constant returns to scale by combining capital and union labor in fixed proportions. The assumption of Leontief technologies in the union sector is primarliy for graphical convenience, though its implications for the endogenous determination of the union wage premium will be discussed below. ${ }^{\prime}$ Goods in the union sector are Indexed according to increasing labor intensity, and the ratio of labor to capital, while uniquely fixed for any good, is assumed to vary continuously between zero and Infinity as $z$ goes from zero to one. Finaliy, domest1c preferences over the entire set of consumption goods $z \in\{[0,1], 2\}$ are assumed to be Cobb-Douglas.

Now consider the forelgn country. As noted above, technology for producing the capltal good is Identical at home and abroad. Further, assume that the Cobb-Douglas preferences over the final goods are shared by both countries. Finaliy, to neutralize any Ricardian basis for trade, it is assumed that, in the production of final goods, an economywide efficiency differential exists between the domestic and forelgn countries which may give rise to an absolute but not to a comparative advantage. That $1 \mathrm{~s}$, defining $\ell(z)$ and $k(z)$ as labor and capital requirements, respectiveiy, for unit production of good $z$ in the 
domestic country, and defining $\ell^{*}(z)$ and $k^{*}(z)$ analogously for the forelgn country, it is assumed that

$$
\begin{aligned}
& \ell^{*}(z)=e \ell(z) \\
& k^{*}(z)=e k(z)
\end{aligned} ; \quad z \in\{[0,1], 2\}
$$

where e measures the efflciency differential between domestic and forelgn production of final goods. A rise in e corresponds to an Inorease in the relative efflclency of domestlc producers.

In the absence of a domestic union wage premium, condition (2) Implies that there wili exist no basls for trade between the two countries. A single equilibrium wage $w$ w1ll be earned by ali domestic iabor, whlle w* wili be earned by labor abroad. Given (1) and (2), and assuming the absence of transportation costs, relative wages at home and abroad must in equilibrium satisfy

$$
e=\frac{w}{w^{*}}
$$

since otherwise one country would have a cost advantage in the production of all traded goods. Under equilibrium condition (3), neither country has a cost advantage in the production of any good and, as a result, the international pattern of production is completely arbitrary.

The introduction of a domestic union wage premium provides the basis for trade between the two countries. A two-quadrant version of the Lerner-Pearce diagran familiar from Heckscher-OhI in trade theory can 
be used to 11lustrate the no-trade equ111brium and how the existence of a domestic union age premium gives rise to international trade. With labor measured on the horlzontal axis and capital measured on the vertical axis, the right and left quadrants of Flgure 1 deplet the unit 1socost ines and unit value isoquants that obtain in the union sector and the non-union sector, respectively, in the absence of a union wage premium. For graphicai convenience, $e$ is set to unity lmplying that technologles are 1dentical in the two countries.

In the absence of a domestic union wage premium, and with e set to one, (3) implies that, in equilibrium, domestic and forelgn wages w11l be identical. Normailing this common wage to unity and using (1), the unit isocost ine plotured in each quadrant of Figure 1 is shared by both countries and intersects each axis of the two-quadrant LernerPearce diagram at one, refiecting the reciprocal of the unitary wage pa1d to labor in each sector and the reciprocal of the unitary price of capltal. Cobb-Doüglas preferences imply that each good will be demanded and thus produced somewhere in the free trade equilibrium, so that f Inai goods prices w111 adjust to ensure that every unit value 1soquant just touches the unit isocost ine in 1 ts sector. Since the unit value 1soquants and unit isocost Iines are shared by the two countrles, zeroprofit production of any good can occur in elther country, and as such, the international location for the production of any final good will be completely arbitrary.

Finally, recall that, in the union sector, each good $z$ is assumed to be produced with a unique ratio of zabor to capital; this too is 
reflected in Flgure 1 . In particuiar, the rat1o $\frac{\ell}{k}\left(z^{\prime}\right)$ for any $z^{\prime}$ e $[0,1]$ can be read from the rlght-hand quadrant of $g$ lgure 1 as the Inverse of the slope of the ray from the or 1 gln through the point on the ourve labeied $z Z$ that lies vertically above $z^{\prime}$. Under the assumption that the zabor-capltal ratio is continious and monotonicaliy increasing in $z$ over the intervat $z \in[0,1]$ with $\frac{l}{k}(0)=0$ and $\frac{l}{k}(1)=\infty$, the $z Z$ curve, which assoctates with each $z \in[0,1] a$ labor-capital rat1o in the way desoribed above, w111 intersect the horizontal axis at one, be continuous over $z \in[0,1]$, and have negative but finfte slope.

Now consider the introduction of an exogenous union wage premiam. $p=\frac{\omega-w}{\omega}$, which ralses above one the wage pald to labor employed in the domestic union sector, wa Since the domestio union wage 1s now nigher than the unitary wage abroad, the domestio price of capital must fall below one if the union sector is to continue to operate at all in the domestio country. This lmplies, using (1), that the domestio nonunion wage must fall. In fact, for any given union premium, the level of the domestlc non-union wage wili determine completery the scope of domestic production and the pattern of international trade. This is deploted in Figure 2.

With the forelgn wage st1li normalized to unity, the forelgn unit 1socost ines continue to intersect each axis of the Lerner-Pearce diagram at one. The domestio unit 1sozost ine in the non-union sector w111 now be given by a line such as $\overline{e d}$ in the left quadrant of Flgure 2, with vertical intercept $\frac{1}{r}$ where $\frac{1}{r}>\frac{1}{r^{*}}=1$, and hortzontal 
intercept $\frac{1}{w}$ where $\frac{1}{H}=\frac{1}{r}$ by (1). The domestio unit isocost ine in the union sector w112 be given by the ine dd in Figure 2, with vertical intercept $\frac{1}{r}$, horizontal intercept $\frac{1}{w}$ where $\frac{1}{\omega}<\frac{1}{w^{*}}=1$, and slope $-\left[\frac{1}{1-\rho}\right]$. The exact position of $\overline{e d}$ and $\overline{d d}$ for any union premium will depend on the jevel of the domestic non-union wage $w$, which can be determined once the demand side of the model is completed.

Finaliy, goods prices will eliminate profits in equilibrium. In the left quadrant of Figure 2 , the unit value 1soquant w11: move out along a radial path from the origin until its vertex 21 es on the outermost unit 1socost ine, that of the domestic country. Accordingly, the non-union good w112 be produced domestically. Similarly, each unit value isoquant in the right quadrant will move along a radial path from the origin until its vertex 11 es on the convex huli of the two unit isocost ines. The good labeled $z$ in Figure 2 is the "marginal" good whose production can occur in elther country in equilibrium, all goods $z \in[0, z)$ produced at home and all goods $z \in(z, 1]$ produced abroad. Consequentiy, in the presence of a domestic labor union, the domestic country specializes in the production of the non-union good, and in the capital intensive goods of the union sector.

The real wage effects of the domestic labor union can also be read from Flgure 2. The forelgn nominal wage $w^{*}$ is unchanged at its normalized value of unity. Prices of goods $z \in[z, 1]$ are also unchanged relative to $w^{*}$. However, prices of goods $z \varepsilon\{[0, z), 2\}$ have falien relative to $w^{*}$ as a result of the domestic union wage premiun, 
as reflected in the outward radial shift of the unit value isoquants for these goods. Therefore, forelgn zabor galng in real terms from the unionization of the domestlo labor force. Th1s occurs because the domestic union wage premium has provided the basis for trade between the two countrles, and forelgn labor enjoys the benefits of this trade. The real wage of those employed in the domestic union sector rises by an even greater amount, shce is inoreases relative to the forelgn wage * However, the domestic labor union causes the wage of laborers employed in the domestio non-union sector to fall in real tertas whth respect to every $800 d$ exeept $z e(0,2)$ which by assumption use ondy non-union labor in thelr product on, and whose prices thereforemove in tandem wh the domestio non-union wage w. Hence for any union wage premlum and domest10 non-unton wage, the Lerner-pearce diagram of F1gure 2 can be used to determine the pattern of production and trade, and the real returns to factors in the two countries.

The next step is to determine the domestio non-union wage w as a Punction of the exogenous union wage premium. To begln, the marginaz $800 d z$ can be defined implicltiy by setting the production cost of $z$ equal in the two countries. Wh the forelgn wage normalized to one, and using the fact that $r w$ by $(1), z$ wili be an lmpl10it function of $w$ and $e$ and of the domestio union wage premium $\rho$ as given by

$$
w\left[\frac{1}{1-\rho} 2(z)+k(z)\right]=e[2(z)+k(z)]
$$


Expression (4) can be manipulated to yleld

$$
\frac{h}{k}(z)=\frac{(1-\rho)\left(1-\frac{w}{e}\right)}{\frac{w}{e}-(1-\rho)}
$$

Define $f(\cdot)=\frac{\ell^{-1}}{k}(\cdot)$. Then (5) can be solved for $z$ as

$$
z=f\left(\frac{(1-\rho)\left(1-\frac{w}{e}\right)}{\frac{w}{e}-(1-p)}\right)
$$

Since the labor-capital ratio is by assumption continuous and monotonicaliy increasing in $z$ over the interval $z \in[0,1]$ with $\frac{\ell}{k}(0)=0$ and $\frac{l}{k}(1)=\infty, f(\cdot)$ wi12 be continuous and monotonicaizy increasing in 1ts argument with $f(0)=0$ and $f(\infty)=1$. As such, expression (6) implies that, for any $0<\rho<1$, w must satisfy $e(1-p)<w \leqq e$. If $w=e, z=0$ by $(6)$ and the domest10 country produces oniy the non-union good: on the other hand, w must be strlctiy less than $e(1-p)$ since if $w=e(1-p)$, then by $(6)$, $z=1$ and the domestic country would produce everything. Finaily, inspection of (6) reveais that $z$ is a continuous and decreasing function of $w$ and of $\rho$, and an increasing function of $e$, or

$$
z=z\left(\begin{array}{ccc}
(-) & (-) & (+) \\
w & \rho, & e
\end{array}\right)
$$

Next, define $\Gamma(z(w, p, e), b(2))$ as the fraction of income spent (anywhere) on those goods in which the home country has a comparative advantage, or 


$$
\Gamma(z(w, \rho, e), b(2))=b(2)+\int_{0}^{z(w, \rho, e)} b(z) d z
$$

where $b(2)$ is the budget share alloted to consumption of good 2 , and $b(z) d z$ is the budget share alloted to consumption of union sector goods $z \in[z, z+d z]$. Then $1-\Gamma(\cdot)$ is the fraction of income spent (anywhere) on goods produced abroad. The properties of $\boldsymbol{z}(w, p, e)$ noted in (7) and the non-negativity of $b(z)$ imply that $\Gamma(z(w, 0, e), b(2))$ is non-1ncreasing in both $w$ and $p$, and nondecreasing in $e$ and $b(2)$. Finaliy, using the fact that preferences are Cobb-Douglas, the fraction of world income captured by the domestic labor union in the form of union rents is given by $R(z(w, \rho, e), p)$ defined as

$$
R(z(w, \rho, e), p)=\rho \cdot \int_{0}^{z(w, p, e)} b(z)\left[\frac{\ell(z)}{\ell(z)+(1-p) k(z)}\right] d z
$$

$\Gamma(z(w, p, e), b(2))-R(z(w, p, e), p)$ is then the fraction of world income recelved by the domestlo labor force, net of union rents.

With $L$ and $L^{*}$ defined as the comestic and forelgn labor force, respectively, and with $w^{*}$ normallzed to one, domestic income $Y$ w1II be given by

$$
Y=\frac{w L+R(z(w, \rho, e), \rho) L^{*}}{1-R(z(w, \rho, e), \rho)}
$$

The equilibrium value of the domestic non-union wage, $\curvearrowleft$, is then determined by the balanced trade condition 


$$
[1-\Gamma(z(\pi, 0, e), b(2))] Y=\Gamma(z(\omega, 0, e), b(2)) L^{*}
$$

or

$$
\omega=\frac{\Gamma(z(\theta, \rho, e), b(2))-R(z(\omega, \rho, e), p)}{1-\Gamma(z(\sigma, \rho, e), b(2))}\left(\frac{L^{*}}{L}\right)=B\left(z(\omega, p, e), p, b(2), \frac{L^{*}}{L}\right)
$$

For any exogenous valie of the union wage premium, $p$, the equizibrium domestic non-union wage can be found as the solution to (11).

Lemma: A unique exists for any $0<0<1$, provided that

$e>\frac{b(2)}{1-b(2)} \frac{L^{*}}{L}$

Proof: From their respective definitions, it foilows immediately that

for $0<0<1$,

$$
\begin{aligned}
& \Gamma(z(w=e, p, e), b(2))=b(2) \\
& R(z(\varphi=e, \rho, e), \rho)=0 \\
& \Gamma(z(\kappa=e(1-p), p, e), b(2))=1 \\
& \mathrm{R}(z(\tilde{z}=\mathrm{e}(1-\rho), p, e), p)<1
\end{aligned}
$$

Consequentiy,

$$
\begin{aligned}
& B\left(\boldsymbol{z}(\boldsymbol{\theta}=e, \rho, e), \rho, b(2), \frac{L^{*}}{L}\right)=\frac{b(2)}{1-b(2)} \frac{L^{*}}{L}<e \\
& B\left(\boldsymbol{z}(\boldsymbol{\theta}=e(1-\rho), \rho, e), \rho, b(2), \frac{L^{*}}{L}\right)=\infty
\end{aligned}
$$


In addition, $[\Gamma(\cdot)-R(\cdot)]$ can be rewritten as

$[\Gamma(\cdot)-R(\cdot)]=b(2)+(1-\rho) \int_{0}^{z(w, \rho, e)} b(z) \cdot\left[\frac{l(z)+k(z)}{l(z)+(1-\rho) k(z)}\right] d z$

Since $z(w, p, e)$ is decreasing and continuous in $w,[\Gamma(\cdot)-R(\cdot)]$ is a noninereasing and continuous function of w, while $[1-\Gamma(\cdot)]$ is a nondecreasing and continuous function of w, so that $B(\cdot)$ is a continuous function of w and

$$
\frac{\partial B\left(z(w, p, e), \rho, b(2), \frac{L^{*}}{L}\right)}{\partial w} \leq 0
$$

Conditions (13) and (15) and the continuity of $B(\cdot)$ ensure the existence of a unique $*$ that solves (11).

Using equilibridm condtion (11), the equlitorium domestio nonunion wage can be determined as a function of $p$ for flxed values of $e$ and $\frac{L}{L^{*}}$. In particular, for $\rho=0$, we know from ( 3 ) that G = e. Further, from their definitions in (8) and (14), $\Gamma(\cdot)$ and $[\Gamma(\cdot)-R(\cdot)]$ are nonlnoreasing $1 \mathrm{n} \rho$ so that

$$
\frac{\partial B\left(z(w, \rho, e), \rho, b(2), \frac{L^{*}}{L}\right)}{\partial \rho} \leq 0
$$

Wth (15) and (16), It foliows from (11) that $\frac{d}{d p}<0$. Finaliy, for $\rho=1$, expression (6) $1 \mathrm{mp}$ iles that $z=0$ which, according to (8) and (9), means that $\Gamma(z(w, p=1, e), b(2))=b(2)$ and $R(z(w, p=1, e), p=1)=0$. Consequently, (11) implies that when $\rho=1, \approx=\frac{b(2)}{1-b(2)} \frac{L^{*}}{L}=\sigma_{m 1 n^{*}}$ 
is is assumed that ${ }_{\text {min }}<e$. The relationship desoribing 7 as a function of $p$ impicit in condition (11) is summarized by the downard sloping curve in Figure 3. For any exogenous union premium, this ourve glves the equilibrium value of the domestio non-union wage.

\section{Hodel Ing Unton Behavior}

The potential importance of making endogenous the pattern of production and trade from the standpoint of determining the effects of forelgn competition on union wage-setting behavior is brought out by noting that trade w12I have two opposing effects on the optimal union wage premium in this model. On the one hand, the union wage w11l be constrained by international trade through a higher elasticity of derived demand for union labor: this results from the international relocation of production that would occur at the margin in response to further increases in the union wage. On the other hand, the goods whose production does remain at home w1ll be those that use relatively unintensively the services of union labor, and the average labor Intensity of production in the union sector will decline: this effect tends to reduce the elasticity of derived demand for union labor, and consequently leads to a higher union wage. If the former effect is Invariant with respect to the scope of domestic production, then through the latter effect, "1ntensiflcation" of forelgn competition which manifests itself in a narrower scope of domestic production will bring about a higher union wage premium, since the increased competition from abroad weeds out precisely those firms whose relatively intensive use of 
union labor held down the domest1c union wage premium. These results are derlved formaliy as follows.

Domestic union membership is taken as exogenously determined. Union members who do not get jobs in the union sector are assumed to find employment in the non-union sector at the prevaliang non-union wage. The union $1 \mathrm{~s}$ assumed to choose $w$ to maximize the rents earned by 1 ts members, taking the domestio non-union wage and level of world income $\left(Y+L^{*}\right)$ as flxed. - Domestic union rents can be written as

$$
\begin{aligned}
\Pi(\omega) & =[\omega-w] \int_{0}^{z(w, \rho(\omega), e)} l(z) d(z ; P(z ; \omega)) d z \\
& =[\omega-w] D(\omega)
\end{aligned}
$$

where $d(z ; P(z ; \omega)) d z$ is worid demand for unlon sector goods $z \varepsilon[z, z+d z]$ and $P(z ; \omega)=\omega l(z)+w k(z)$ is the price of good $z$. World income has been suppressed as an argument of demand since 1 t is by assumption taken as given by the domestic union. The first order condition for the union's probiem is

$$
\frac{\partial \Pi(\omega)}{\partial \omega}=D(\omega)+(\omega-w) \frac{\partial D(\omega)}{\partial \omega}=0
$$

Manipulation yields an expression for the optimal union premium

$$
\tilde{p}=\frac{1}{7}
$$

where $n=\frac{-\partial D(\omega)}{\partial \omega} \frac{\omega}{D(\omega)}$ is the elasticity of derived demand for domestic un ion labor with respect to $w$ with the sign reversed. 
The derlved demand elasticity $n$ can be broken into two components, one associated with changes in derived demand for each linion good holding the scope of domestic production constant, and the other assoclated with changes in the scope of domestio production itself. Explicit caicuiation of $n$ yieids

$$
\eta=\int_{0}^{z(w, \rho, e)} x(z ; z(w, \rho, e), \rho) \theta(z ; \rho) d z+\sigma
$$

where

$$
\theta(z ; p)=\frac{\omega \ell(z)}{P(z ; \omega)}=\frac{\ell(z)}{\ell(z)+(1-p) k(z)}
$$

is the domestic union labor's share of production costs for good $z$,

$$
k(z ; z(w, \rho, e), \rho)=\frac{b(z) \theta(z ; \rho)}{\int_{0}^{z(w, \rho, e)} b(z) \theta(z ; \rho) d z}
$$

1s the share of derlved demand for domestic union labor assoclated with $\operatorname{good} z$, and

$$
\sigma=-\omega \frac{\partial z}{\partial \omega} \lambda(z(w, p, e) ; z(w, \rho, e), p)
$$

is the elasticlty of derived demand for domestic union labor associated with the international relocation of the production of marginal goods. According to (20). $n$ can be written as the elasticity of demand for domestic union labor associated with changes in the scope of domestic 
production, $\sigma$, plus a welghted average of derived union labor demand elasticlties across goods produced in the domest10 union sector which, due to the Cobb-Douglas demand and Leontlef technology assumptions, are given by the union cost share variable $\theta(z ; p)$. If The optimal union premium according to (19) is simply the inverse of this sum.

Glven e, (19) defines the equilibrium $p$ as a function of $w$. A suffletent condition for $\delta \varepsilon[0,1)$ to exist for a given $w$ is that a exceed one. Since (6) implies that $\frac{\partial z}{\partial w}=-f^{\prime}(\cdot) \frac{e-w}{(w-e)^{2}}, 0$ w1II be greater than one over the relevant range of w's provided that $f^{\prime}(\cdot)$ is sufflelentiy large, 1.e., provided that variation in labor-capltal ratios across $z$ in the relevant range is not too large. The second order condition wily aiso be met provided that $\mathrm{f}^{\prime}(\cdot)$, and thus $\sigma$, 1 s sufflolentiy large at the optimum. Tris is assumed to be the case. Elnaliy, it is assumed that the distribution of budget densities and 1.) are such that $\sigma$ ls invariant with respect to changes In the scope of domestic production in the relevant range. It is then easily shown from (19) that, provided second order conditions are met,

$$
\frac{d p}{d w}>0
$$

The relationship desoribing: $\beta$ as a function of $w$ ls libutrated by the upward sioping ourve in Figure 3.: For given values of $w$, this curve gives the value of $\rho$ satisfying the rent-maximizing conditions of the union. The solution to the two equiliorlum conditions of the 
model, equations (11) and (19), is 11lustrated in Figure (3) as $(\bar{w}, \bar{p})$. Finaliy, having determined general equilibrium values for the union wage premium and the domestio non-union wage in Figure 3, Figure 2 can be used to determine the real wages pald to those empioyed in the union and non-union sectors at home, and to labor abroad, and the equilibrium pattern of production and trade. The next section expiores how the endogenelty of the union affects several comparative statics results of the model.

\section{Comparat1ve Statics}

The model developed in the previous section can be used to 1Ilustrate the effects of changes in the international environment on union behavior. Th1s section explores the union response to three events: a shift in consumer preferences toward non-union goods, the imposition of a domestio targeting program almed at union-sector goods, and the international migration of non-union Iabor.

\section{Demand Shifts}

Lawrence and Lawrence (1985) provide an explanation for the rising union wage premium in the U.S. over the pertod 1970-1984 which is based on a prediction of rising union wage differentials in response to iong run declines in demand growth: the decline in demand growth in the union sector reduces the substitution possiblilties between capital and labor, leading to a less elastic derived demand for union labor and a greater wage premium. The model of section II ylelds a similar relationship between decilning union sector demand and rising wage 
differentials, but for a very different reason.

Consider an increase in $b(2)$, the proportion of income spent on the non-union good, accompanled by a proportional decrease in the budget shares of alz union sector goods $z \varepsilon[0,1]$, so that $\lambda(z ; \cdot)$ is unchanged for $z \varepsilon[0,1]$ and the budget shares over all final goods still sum to one. The decilne in union sector demand will have no affect on the equilibrium relationship between $\bar{d}$ and $w$ given by condition (19), since $b(2)$ does not enter (19) directly (see the definition of $n$ given in $(20)$ ). Combinations of $p$ and $w$ that satisfy (19) are deploted by the upward sioping curve in Figure 4. However, $b(2)$ does enter Into equiliorium condition (11). For any p>0, the increase in $b(2)$ w11l lead to a domestic trade surplus which, according to $(11)$, requires a $r$ ise $1 \mathrm{n}$ w to restore equ111brium. If $0=1$, then $(11)$ 1mplies that $=\frac{\mathrm{b}(2)}{1-\mathrm{b}(2)} \frac{\mathrm{L}^{*}}{\mathrm{~L}}=\mathrm{F}_{\mathrm{min}}$ so that $\mathbb{A}_{\mathrm{m} \text { in }}$ must $\mathrm{rise}$ wth an Increase in $b(2)$. If $\rho=0$, then wee and the location of production is arbitrary, so that changes in budget shares have no affect on relative wages. This is summarized by the upward shift in the negatively sloped ourve shown in Figure 4 , which deplcts the relationshlp between a and $p$ given in (11).

At the original $\bar{\rho}_{0}$, the domestio non-union wage is bid up relative to the wage of forelgn labor due to the shift in preferences away from goods of the union sector and toward good 2 t this makes domestlo union sector production less competitive relative to production abroad, and the production of a marginal range of domestic union goods is lost to forelgners. Since the domestic plants that close are the 
most labor intensive of the domestic union sector, the sectorat labor intensity of the domestic union sector declines, inducling the rentmaximizing union premium to rise. The new equilibrium is 1IIustrated in F1gure 4 by $\left(w_{1}, \bar{p}_{1}\right)$, where the union premium nas risen as a result of the decining demand for union sector goods.

Fundamentally, it is not the decilne in union sector demand per se but rather the loss of marginal goods associated with it that leads to a rise in the domestic union wage premium. The loss of marginal goods is brought about by an increase in the domestic non-union wage resulting from the greater demand for domestio non-union workers. As such, the model associates rising union wage premiums with faling union sector demand only when, as in the proportional case considered here, the shift in demand away from the goods of the union sector results in greater demand for the services of domestic non-union labor.

\section{Targeting}

As Krugman (1987) has noted, the case for industrial targeting stands or falls with the ablity to identify sectors that "ought" to be targeted, where targeting is understood to lmply a polloy of affecting the sectoral pattern of investment rather than its aggregate level. Since the cholce of the targeted sector w11l have implications for the scope of domestic union production in the model of section II, it will also affect the union wage premium. This in turn can provide a reason to alter the sectoral mix of investment through a poilcy of industrial targeting.

As an 121ustration of this polnt, consider the cholce between 
allocating a given amount of R\&D expenditures to elther the union or the non-union sector of the domestic country, where the direct (cost-saving) effect of the R\&D resuits in an inorease in $e$ in the targeted sector. Assume that the change in e alone would lead to cost reductions for the domesticaizy produced goods of the sector which $1 \mathrm{mply}$ an equivalent increase in utlitity regardiess of the sector chosen for targeting. Thus, from the standpoint of the direct effect of R\&D, there is no basis upon which to favor one sector over the other.

If the non-union sector were targeted, ali benef 1 ts would be captured in this direct effect: the increase in the domestic effloiency of the non-union sector and the resulting drop in $P(2)$ would be the oniy benefit of the program, since endogenous variabies of the model would be unaffected. This is easizy seen by noting that e enters both equilibrium conditions $(11)$ and $(19)$ only through $z(w, 0, e)$, and hence, only in so far as it captures the international technology differences In production of union sector goods. As sion, the domestic ut litty beneflts of R\&D applied to the non-union sector are captured completely by the resulting price reduction for good 2 .

Not so for a pollcy of targeting the domestio union sector which, In altering the efflclency of production of the marginal union good, affects the equilibrlum values of w and p. Spectficaliy, consider frst the lmpact of an increase in: $e$ on equilibrium condition (11). The efflolency parameter e enters (11) only through 1 ts affect on $z(w, p, e)$ as given in expression (6). Thus, for any $0<p<1$, Implies that an increase in e would require an equivalent percentage 
Increase in $w$ to leave $z(w, 0, e)$, and hence $B(\cdot)$, whohanged. Eut this wolid leave greater than $B(*)$, and hence for (11) to be satisfied, must rise by less than the percentage inorease in $e$. For $\varphi=1, \%$ is unaffected by the change in e since $=*_{\min }=\frac{b(2)}{i-b(2)} \frac{L^{*}}{L}$, while for $\rho=0$, (3) implies that $\sigma=e$ and thus rises by the fuli inorease in $e$. This information is refiected in the jpward shift (by less than the percentage inorease in e) of the negatively sioped ourve in Figure 5a. Next consider the effect of inoreasing e on equilibnim condition (19). Hoiding constant, (6) 1mples that must rise by the sane percentage as e to leave $z$, and hence $1 / \pi$, unohanged. Thus, the upward sloping curve in Figure $5 a$ shifts up by the same percentage as the change in e. The resulting equilibrium $\left(\bar{w}_{p}, \bar{p}_{\eta}\right)$ is given in figure $5 a$. At the original $\bar{\theta}_{0}$ the scope of domestic undon sector production would inorease as a result of the targeting program, since according to (11) the tomestic non-union wage does not rise to fully of fset the cost aavings resuiting from the technologioal advance. Since the additional plants added to domestio union sector production are more labor Intensive than existing domestic production, the sectoral labor intensity of the domestic union sector rises, causing the rentmaximizing union premium to fali. The final equilibrium is given by $\left(\bar{w}_{1}, \bar{p}_{1}\right)$, where the domestie non-unton wage has inoreased and the domestic union premium has fallen as a result of the union sector targeting.

The welfare implications of the change in $\bar{w}$ and $\bar{p}$ induced by 
union-sector targeting are 1ilustrated in Figure $50.8 /$ The unit isocost Ines of the forelgn country are given by the solid Ilnes. Assuming that technologies are or1glnally 1dentical, 1.e., that $e_{0}=1$, the originat unit isocost ines of the comestio country are given by the dashed Ines. With R\&D targeted to the domestic union sector, e will rise above one 1 in that sector. Hoiding o fixed. Figure 5a snows that w (and thus r) rises, but by iess than e, to w'. The dotted ines in the two quadrants of Figure 50 reflect this new equilibrium value of $w$, where $\rho$ has been held flxed. The rise in $w$ and $r$ shifts lnward the domestic unit isocost ine in the non-union sector, as depleted in the left hand quadrant. In the pight hand quadrant, the forelgn country's unit value lsoquant w1:1 be the domestic country"s "e" value 1soquant, since the two countries no longer share technologies for production of the union goods. As such, the domesto union sector's "e" Isocost ine 1 s depleted by the dotted ine in the right hand quadrant. At the originat $\bar{p}_{0}$, it has shifted out, since w fand thus ro has fallen relative to e.

Even before aliowing $\rho$ to respond, it is apparent from Elgure $5 b$ that a terms-of-trade argument can be made for targeting the union sector in this model, since domestic wages (union and nonunion) increase not only with respect to the prices of domestlcaliy produced union sector goods (the direct effect), but also with respect to the prloes of al1 goods produced abroad (the terms of trade effect). In contrast, targeting the non-union sector leads only to a direct real wage effect with respect to the non-union good, since it leaves the (doubie 
factoral) terms of trade unaztered. This result, however, has nothing to do with the operation of the union per se: It cocurs simply becaluse the union sector happens to include the marginal good, on whose relative production effloiency the relationship between domestio and foretgr wages depends. gl

The reat case for targeting the union sector comes from the aditional effect of the targeting poinoy once the union is allowed to react, As shown in Figure 5a, p falls, inducing w torise further from $w^{\circ}$ until the new equilibrium $\vec{p}_{\hat{p}}$ and $\vec{w}_{1}$ are reached. The dash-dot ines in Figure 50 refiect this finad equilibriun. The additional welfare galns to domestio non-union workers that arise from the union response come in the fort of lower priced union sector goods produced domesticaily and 20 wer priced imports from abroad. As a result of the fail in $p$ and the acompanying znorease in $\%$, the donestic non-union wage rises with respect to the prices of all goods

$z \varepsilon(0,1]$ : the relative wage inorease makes forelgn produced goods more affordable at home, while the drop in $\rho$ lowers the price of domesticaliy produced union sect or goods relative to the domestio nonunion wage. Firally, the domestic union members must benef it in real terms as well from the union's response to the targeting program, even though the union is assumed to ignore its effect on when choosing p. This 18 because the drop in the union premium serves to inorease the domestic non union wage, and hence the (1gnored) double factoral terms of trade effect of the union response is in this case beneficial to domestio union workers. 
Therefore, the reduction $1 \mathrm{n}, \mathrm{p}$ and accompanying 1nerease $1 \mathrm{n}$ w brought about by union sector targeting 1s welfare enhancing for the domestlo economy, and suggests a rationale for carlng especiaizy about the "compet1tiveness" of the union sector. $10 /$

\section{Labor Migration}

International Iabor migration can be represented in the model as a change in $\frac{L^{*}}{\mathrm{~L}}$. In the competitive model explored in Dornbusch, Fischer, and Samueison (1977), labor migration from the low wage to the high wage country would reallocate the world stock of labor toward the country whose marginal-good technology is most efflclent. Th1s serves to expand the wor 2 d production possibl11ties frontier, and makes labor In the low wage country better off, though the (original) inhabitants of the high wage country suffer a welfare decline. of course, the expansion of world production possitilities ensures that the gainers could compensate the iosers. Findlay (1982) has argued in the context of a Rlcardlan model that, with regard to several well-known notions of distributive justice, free trade cum migration 1s "just" in that it at once expands the world production possibilities and brings about a more equal international distribution of income.

In the model of section II, the consequences of Iabor migration $1 \mathrm{n}$ response to international wage differentials can be quite different. First, the union can cause the less efflcient country to have the high non-union wage, so that (non-union) labor migration in the direction of higher wages contracts the world production possiblilties frontier. Moreover, in response to this migration abroad, the scope of domestic 
production contracts, and the union wage premium therefore rises, offseting the real galns that would otherwise acorve to domestic nonunion workers and reducing the amount by which migration closes the internationat non-union wage discrepancy.

This is lilustrated in Figures 5a and 6b. Figure 6a 1i1ustrates the inflal determination of $\bar{p}_{0}$ and $\bar{w}_{0}$ where, as drawn, $e>1>F_{0}$, 1.e., the home country 15 more effletent in the production of all final goods than the forelgn country, but the domestio union wage premium has rediced the domestio non-inion wage below the unitary wage of labor abroad. The solid lines in figure 60 reflect forelgn unit Isocost IInes, while the dashed Ines represent the home country"s inftial "e" isocost ines.

With the initial domestio non-union wage lower than the wage abroad, migration w12l ocour in the direction of the foreigr country. As such, (L*/L) Increases, and Labor migrates towards the technologicaliy inferior country. This wi1 have no effect on the upward sloping curve in Flgure $6 a$, as can be seen by noting that $\left(\frac{L *}{L}\right)$ does not enter directly into equlilbrium condition (19). However, equilibrium condition (11) Implies that the downard sloping ourve in Figure 6 a wil shift upward: for $\rho=1$, the percentage increase in the domestic wage w11l equal the peroentage increase in $\left(\frac{L^{*}}{L}\right)$, while for $p=0$, equals $e$ and is unaffected by relative changes in the size of the domestic labor force.

At the initial $\bar{P}_{0}$, the Increase in the domestio non-union wage that results from the exodus of non-union labor will contract the scope 
of union sector production in the home country. Since the most zaborIntensive activities are the first to go, the sectoral labor intensity of production in the domestio union sector declines, Inducing a rise in p. The finat equilibrium is given by $\left(\bar{\rho}_{1}, \bar{w}_{1}\right)$ in Elgure $6 a$, where both the union wage premium and the domestio non-unton wage have Increased as a residt of the migration.

The rea: wage effects of this migration are contained in Figure 60. The dotted Ines represent the fina1.. "e" 1socost ines for the home country, and reflect the fact that both w and $\rho$ have Increased. The $1 \mathrm{mpl}$ lcations of the union response to migration for the ut1ity of forelgn workers is ambiguous: for a given domestic non-union wage the higher $\rho$ makes domestio goods more expensive abroad, while the drop in the domestio non-union wage induced by the increase in. makes them cheaper. Overali, however, forelgn residents must be hurt by the influx of labor, since both $w$ and $\rho$ rise. The effect of the unton response to migration on the utllity of domestic non-union workers 1s unamb1guousiy negative, since the rise in $p$ diminishes the purchasing power of the domestio non-union wage with respect to domesticaily produced union sector goods, and the induced faid ln w makes goods abroad more expensive as well... The overal 1 effect of the migration on domestic non-union residents is amblguous, however, due to the rise in both $w$ and $p$. If domestlcaliy produced union goods enter with sufficient weight in ut1lity, the (remaining) domestio nonunion labor force w11l be made worse off by the exodus of domestic labor. 


\section{Conclusion}

Competitive trade theory suggests that freely working market forces In a worid economy w11l determine optimaliy the international location of production, and that a colintry engaged in trade need have no additional concerns over the identity of sectors operating within its borders. While recent ilterature has questioned this result, and points toward the potential national benefits of the domestic location of sectors with certain attributes, the focus has been primaridy on product markets.11/ Moreover, there is nothing inherentiy perverse about the free trade aliocation of production across countries in this iiterature: there simply exist certain sectors that all countries would rather have operating within their borders.

This paper has focused on the existence of an optimizing labor union, and has explored the interaction between union wage demands and the international pattern of production and trade. In the modei considered; the scope of domestic production takes on a speclal welfare significance of its own, since it determines in a systematic way the characteristics of the set of firms served by the trade union. A oroader scope of production at home is associated with a Iower domestio union wage premium, while an "Intensiflcation" of forelgn competition Leads to a higher domestic union premium.

As lilustrated in section. II, this relationship implies severaI conciusions concerring the effects of changes in the international environment which lead to shifts in the international pattern of production. First, a shift in preferences away from union sector goods 
and 1 nto the non-union goods of the domestio country w1II, in driving up the domestio non-union wage relative to the wage abroad, diminish the scope of domestic union sector production and hence reduce the sector $\mathrm{I}^{\mathrm{T}}$ labor intensity of production: this leads to a rise in the rentmaximizing domestio union wage premizm. As such, the moded predicts a rising union premium in the face of declining demand for union products.: Second, directing domest10 R\&D efforts toward the union sector w112 expand the scope of union production and reduce the union premium, while R\&D in the non-union sector ieaves the scope of union sector production, and hence union behavior, unchanged: this ralses the posslbility of welfare gains from a program of union sector targeting. Finaliy, International zabor migration can have very different effects when a labor union 13 present. In paticular, the presence of a union in the technologicaliy nore advanced country can cause migration of nonunion labor to occur in the direction of the less advanced country. Moreover, as this migration takes place, the union wage premilum is driven up, of fsetting the welfare galns of migration to the remalning non-union population in the domestic country.

The Inverse relationshtp between scope of production and the unton premium which emerges from this model depends orltically on the notion that international differences in union activity are an 1 mportant determinant of international cost differences. An extreme view has been adopted here, in that the presence or absence of a union is alI that distinguishes countries in the model. The interaction of labor union act1vity w1th other determinants of trade patterns, as well as with the 
actions of other unions at home and atroad, is olearly a direction for purther researoh. 


\section{Refer ences}

Diewert, W. Erwin, "The Effects of Unionizacion on wages and

Employment: A Ceneral Equ1z1ortum Analys1s," Economio Inqu1ry 12, (September 1974): 319-339.

D1x1t, Avinash K., and Gene M. Grossman, "Trade and Protection with

Multistage Production," Review of Economic Studies 49, Coctober $1982): 583-594:$

Dornbusch, Rudiger. Stanley Elscher, and Pali Samuelson, "Comparative Advantage, Trade, and Payments in a Rlcardian Model with a

Continuum of Goods," Amer1can Economic Rev1ew 67, (December 1977): $823-839$.

Findiay, Ronald, "International Distributive Justice," Journat of

International Economics 13. (A.gust 1982): 1-14.

Freeman, Richard, and James L. Medoff, "The Impact of the Percentage

Organized on Union and Nonunion Wages," Review of Economics and

Statistics 63, (November 1981): $561-572$.

Freeman, Richard B., and James L. Medoff, "Substitution Between

Production Labor and Other Inputs in Unionized and Nonunionized

Manufacturing," Review of Economics and Statistics 64, (May 1982):

$220-233$

Grossman, Gene M. "International Competition and the Unionized Sector," Discussion Papers in Economics \$29. Princeton University, 1982.

Hill, John, "Comparative Staties in General Equilibrium Modeis with a Unionized Sector." Journal of International Economios 16, May $1984): 345-356$ 
Hirsch, Barry T., and Mark C. Eerger. Wun on Membership Determatnaton and Industry Characteristics, "Southerm Economio jounai 50, (tanuary 1984$): 665-79$.

Itoh, Motoshtge, and Kazuharu Kiyono, "Wel Fre Enhancing Export Subsidies," Journal of Pol tolcal Economy 95 , (Eebruary 1987): 115137.

Johnson, Harry $G$, and Peter Mieszkowst. "The Efrects of Undonization on the Distribution of Income: A Cereral Equilibrium Approach" Quarteriy Journai of Eonnonics 84, (Novenber 1970): $539-569$. Gones, Ronald H. Histributions in Factor Markets and the General Equilibrium Model of Production," Journat of Pol1tieal Economy 73 , (December 1965): $557-572$.

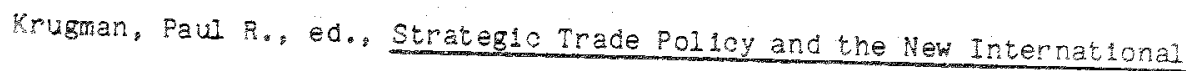
Eoononics, Cambridge, Mass. MIT Press, 1986.

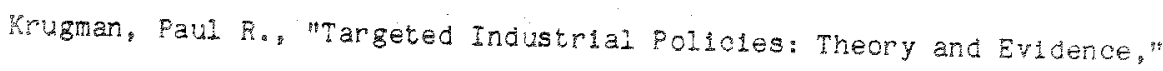
An Doninick Salvatore ed. The New Protectionist Threat to Horld Helfare: 1987, North Holland.

Lawrence, Colin, and Robert Lawrence, "The Dispersion in U.S.

Manufacturing Wages: An Endzame Interpretation, Brookings papers on Economic ketivity, 1985:47-106.

Magee, Stephen, "Factor Market Distortions, Production, Distribution, and the Pure Theory of Internationai Trade:" Quarteriy Journal of Economics 85, (November 1971): 623-643.

MODonald, Ian $\mathrm{M}$, and Robert $M$. Solow, "Wage Bargaining and Employment," American Economic Review 71, (December 1981): $896-908$. 
Oswald, Andrew J., "Trade Unions, Wages, and Unemployment: What Can S1mple Models TeII Us?" Oxford Economic Papers 34, November $1982): 526-545$.

Staiger, Robert W., "Upstream Monopoly in a Ricardian Continuum-of-Coods Trade Model," In Essays in International Trade, Ph.D. D1ssertation. The University of M1chigan, 1985. 


\section{Footnotes}

* This paper has benefited substantialy from the detalied and insightil coments of Aan Deardorff and Robert Stem, from helpful disoussion with John Pencavel, Guldo Tabelini, and members of the International Trade Seminars at Stanford and Princeton, and from the very helpful coments of an anonymous referee. Any remaining errors are my own.

- See, for example, Johnson and Mileszkowki (1970), Jones (1971), Magee (9971), and Dlewert (1974).

2 See, for example, Oswad (1982) and Hil (1984). Grossman (1982) has rocused on modeling the response of union wage demands to an increase in international competion when the union follows a senforty layof and rehing ruie. Hig residts guggest that such hing rules could be responstbie for the enplrical observation that sectoral wages often fall to fall in response to a reduction in the price of competing import goods. The resuits of this paper provide an alternative explanation for such wage behavior.

3 The effect of capitad intensity on the derived demand elasticity for labor is often eited as one explanation of greater union activity in more capitai intensive sectors. For empirical evidence on this relationship, see, for example, Hirsch and Berger (1984).

4) For example, Rloardian trade theory singles out technologioal Gifferences as the determinant of trade patterns, while Heckscheronlin theory foousses on differences in relative factor endowments. 
5/ What is important is not that the elastielty of factor substitution is zero for goods in the union sector, but that it 1s the same across goods. Footnote 7 contalns a discussion of varying factor substitution elasticities. Note aiso that, at the sectorai level, factor substitution w112 occur in response to changing relative factor prices, but 1t w1Iz be accomplished by altering the mix of goods produced within the sector, rather than by altering the mix of factors in the production of any good.

6/ As noted in HiL (1984), rent-maximizing behavior is a special case of the union objective function employed by MoDonald and Solow (1981), in which union members are risk neutral. That the union Ignores its effect on the domestic non-union wage and level of world 1 ncome when setting 1 ts wage $1 \mathrm{~s}$ an assumption which can be motivated by thinking of this union as one of many unions, no one of which is large enough to affect aggregate varlabies, but which together have a signiflcant impact. For a paper focussing on many small unions in a continuum-of-goods general equilibrium model, see Stalger (1985)

If More generally, the elasticities of factor substitution and product demand w1I also enter into the determination of the derived demand elastlclty for union workers. However, emplrical evidence of uniformy low substitution elasticities between union and non-union Inputs can be found in Freeman and Medof $f(1981,1982)$, and it seems natural to focus on variations in cost shares as the main element of heterogenelty among goods served by the union. Limited. 
variation in factor substitution and/or demand elasticlties across goods would complicate but not alter the conclusions of this paper.

8f The $z Z$ curve 13 suppressed from figures $5 b$ and $6 b$ since $1 t$ remains unchanged throughout.

9' An argument for targeting "marginal" goods due to this terms of trade effect has been made recentiy by Itoh and K1yono (1987).

10 The polioy of targeting analyzed here assumes that the union takes as given the government R\&D decision when it sets its wage demands. 11 See krugnan (1986) for a recent review. 


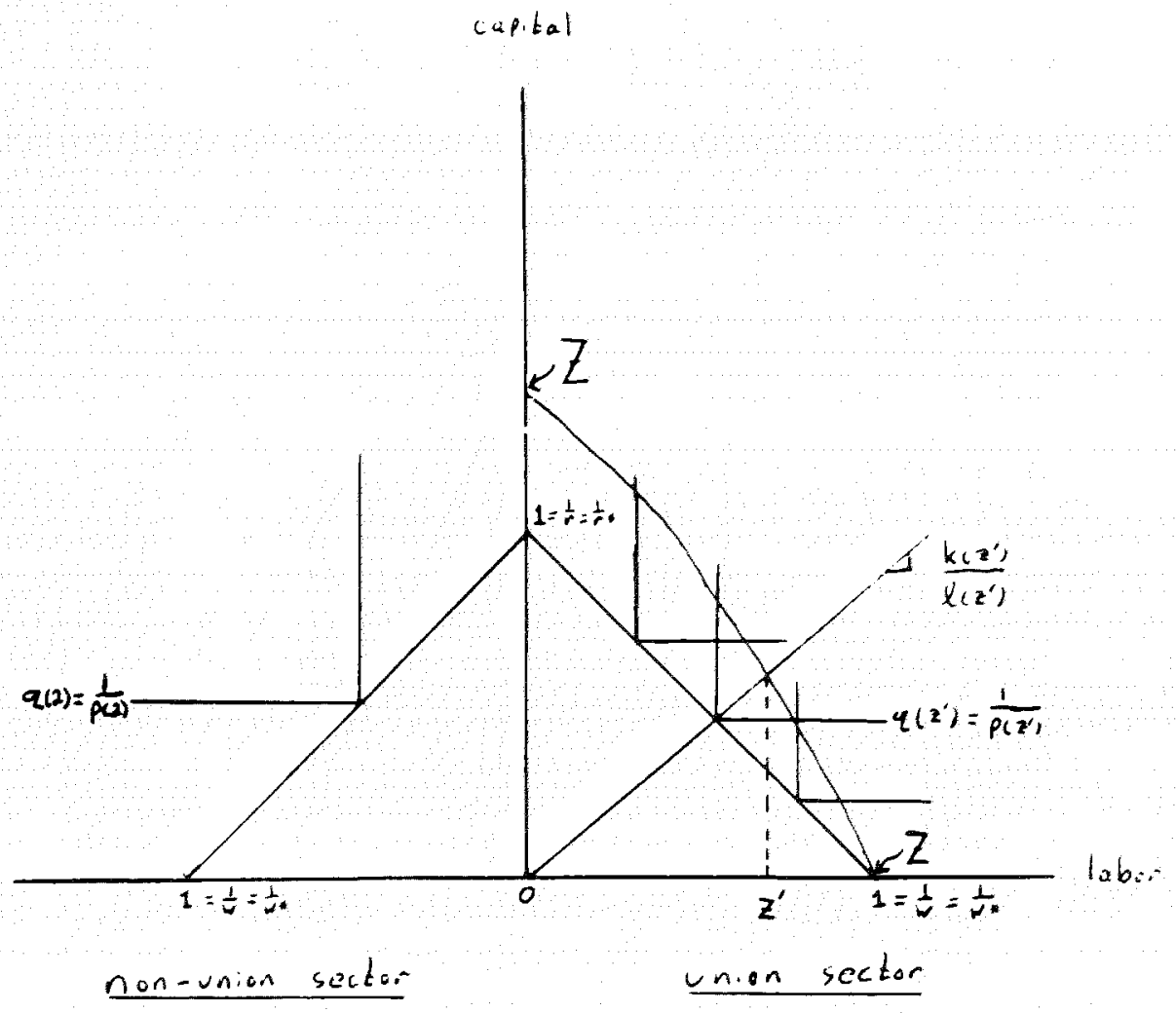

Figure 1 


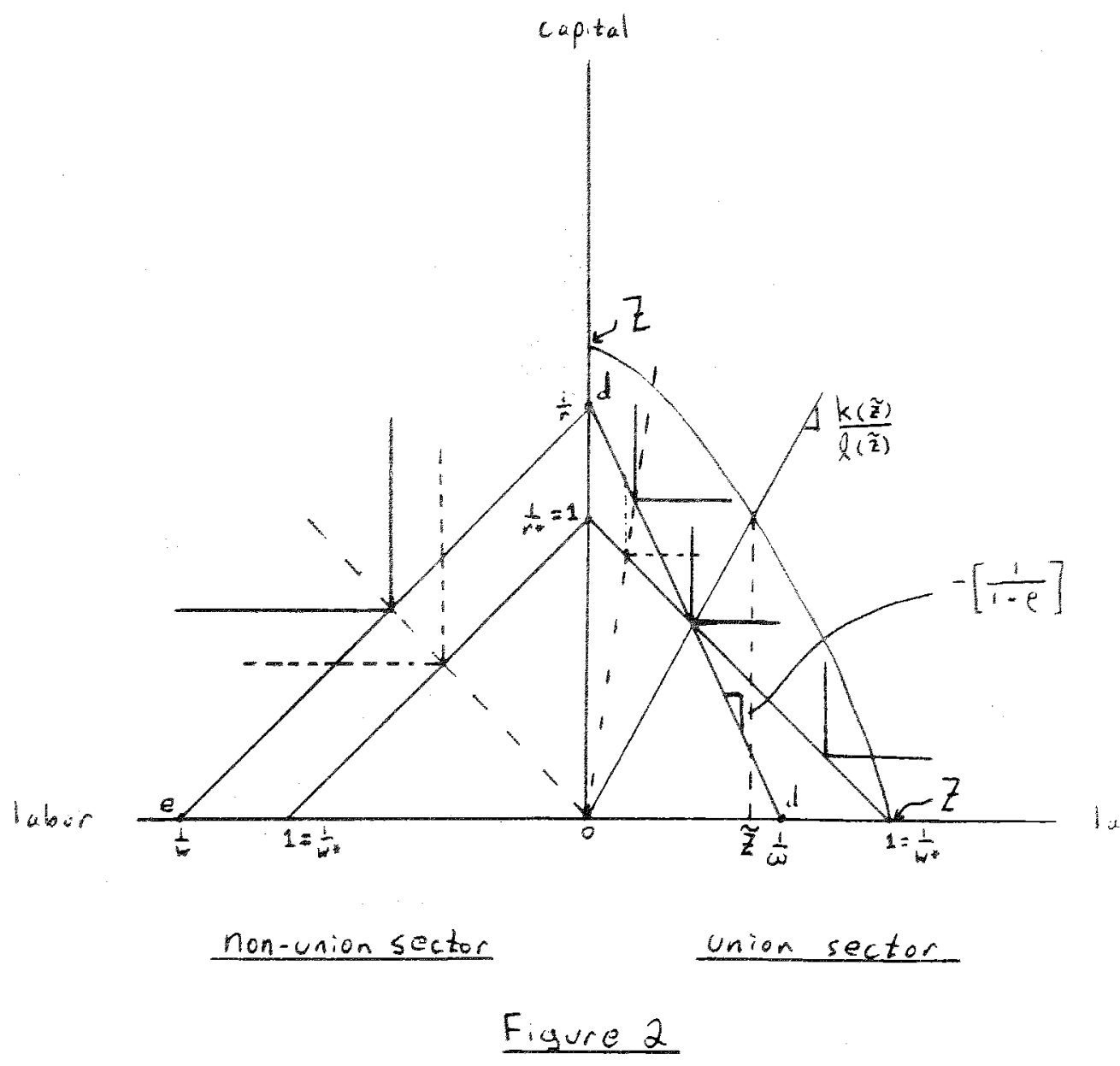




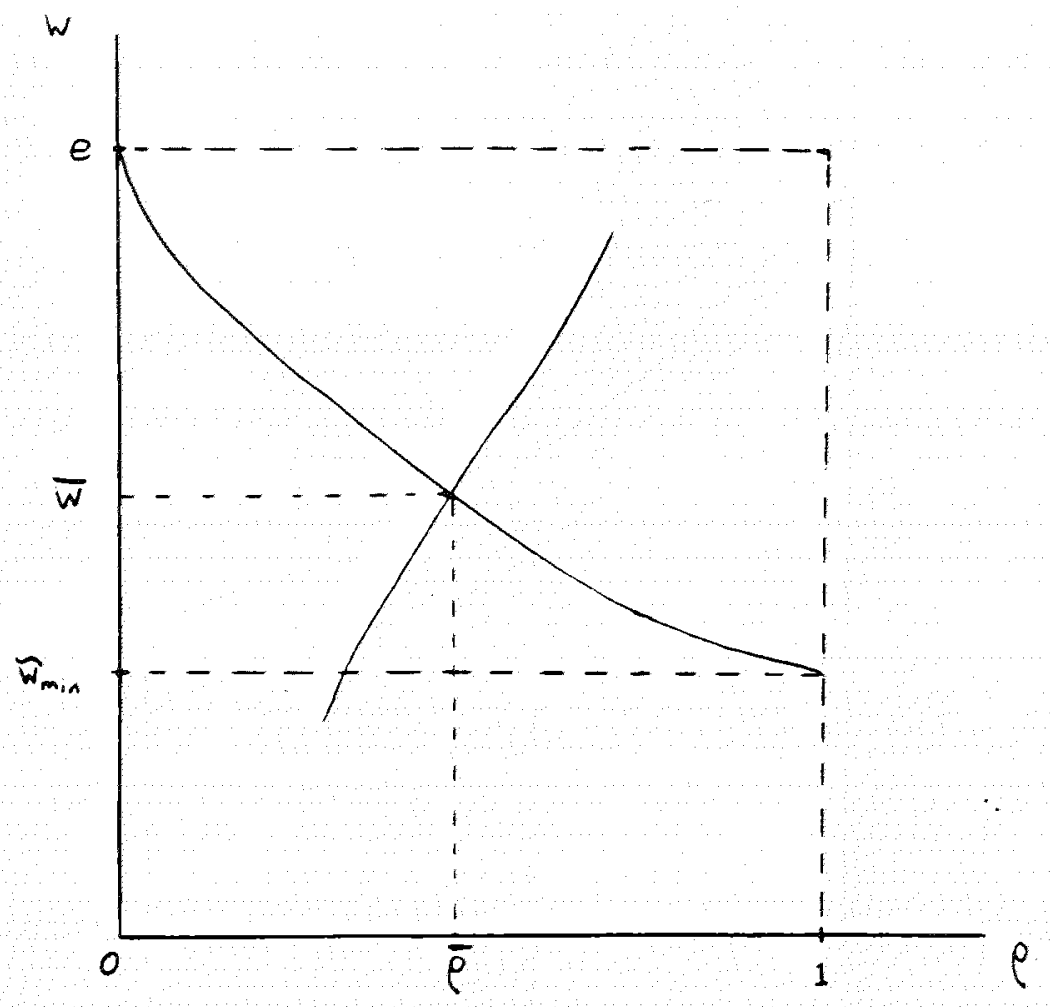

Figure 3 


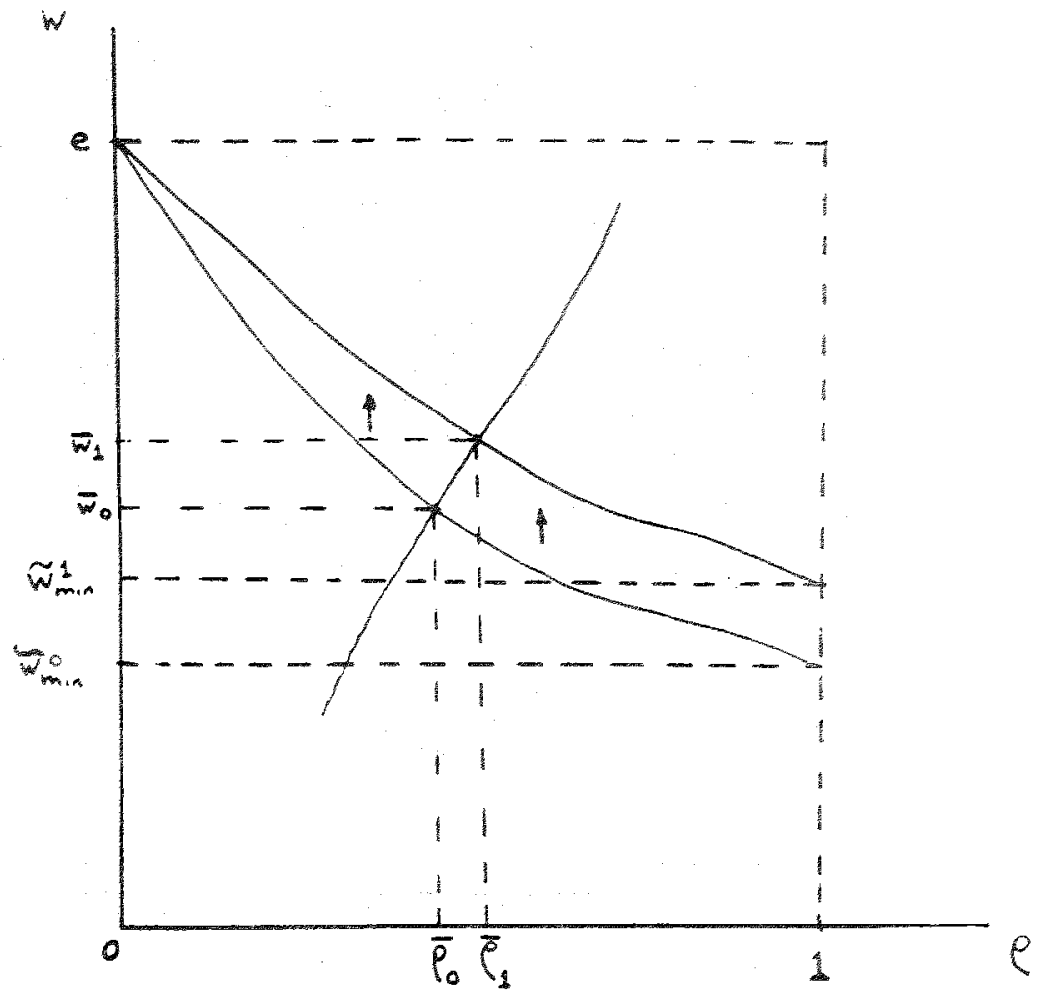

Figure 4 

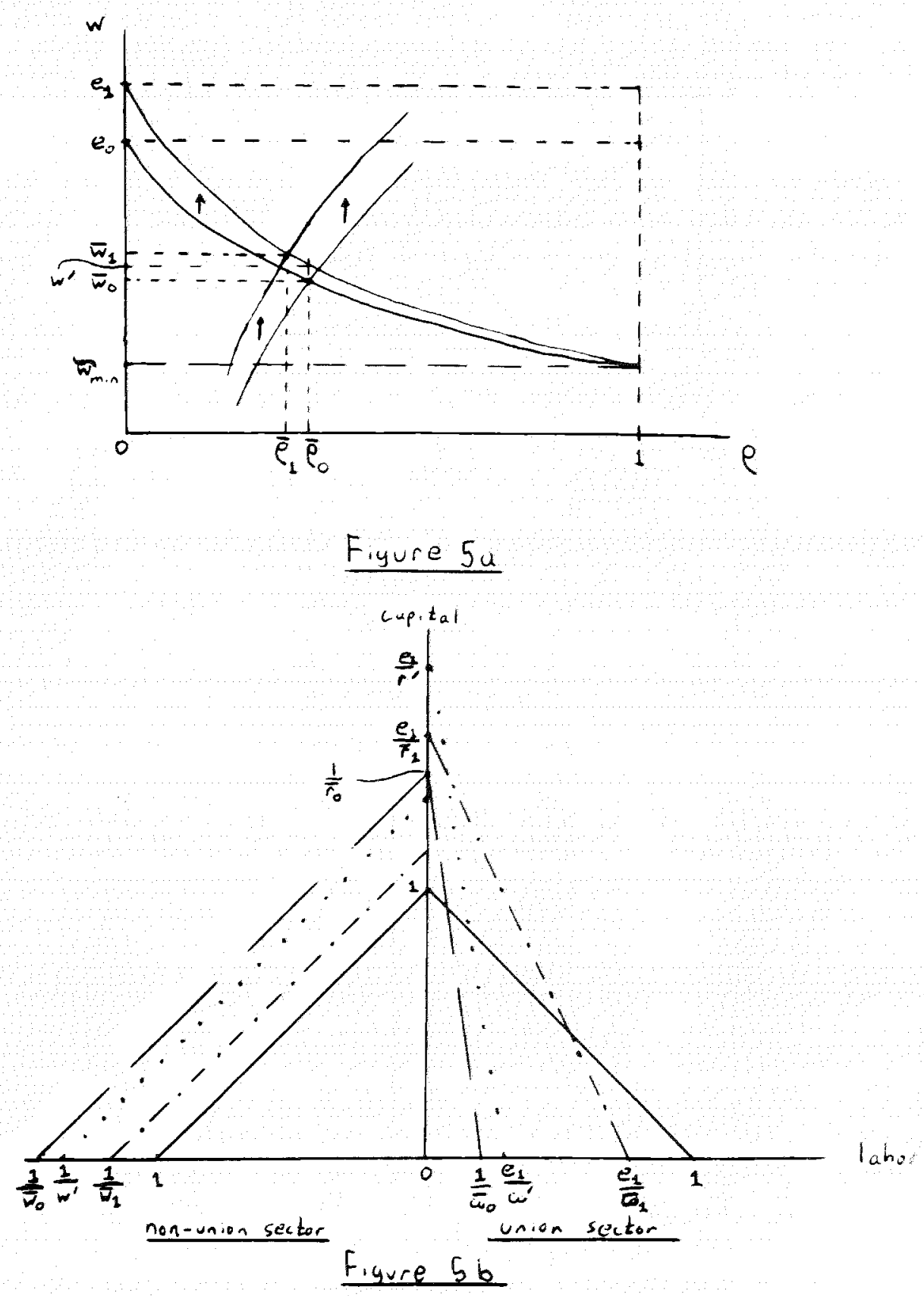


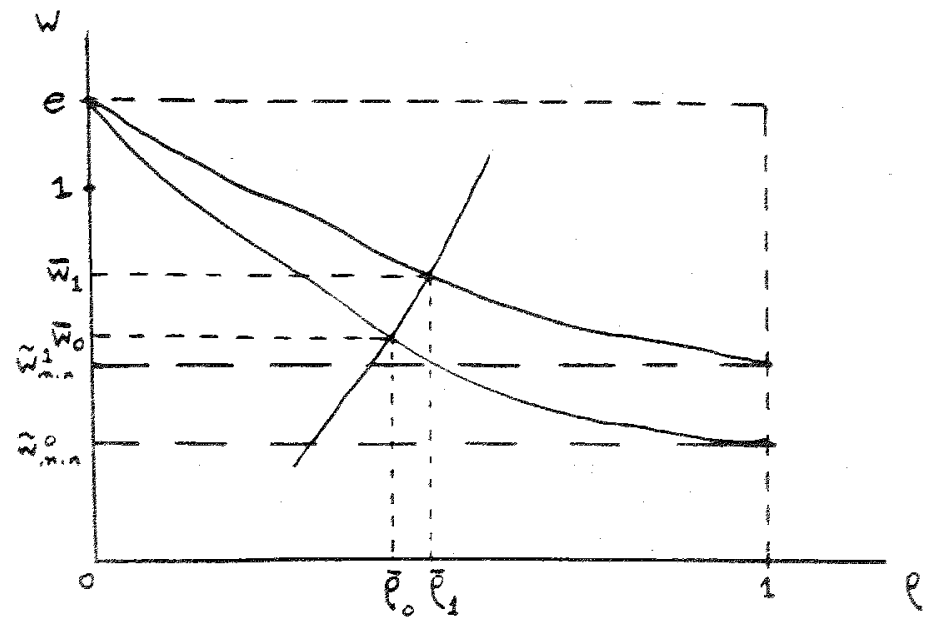

Figure ba

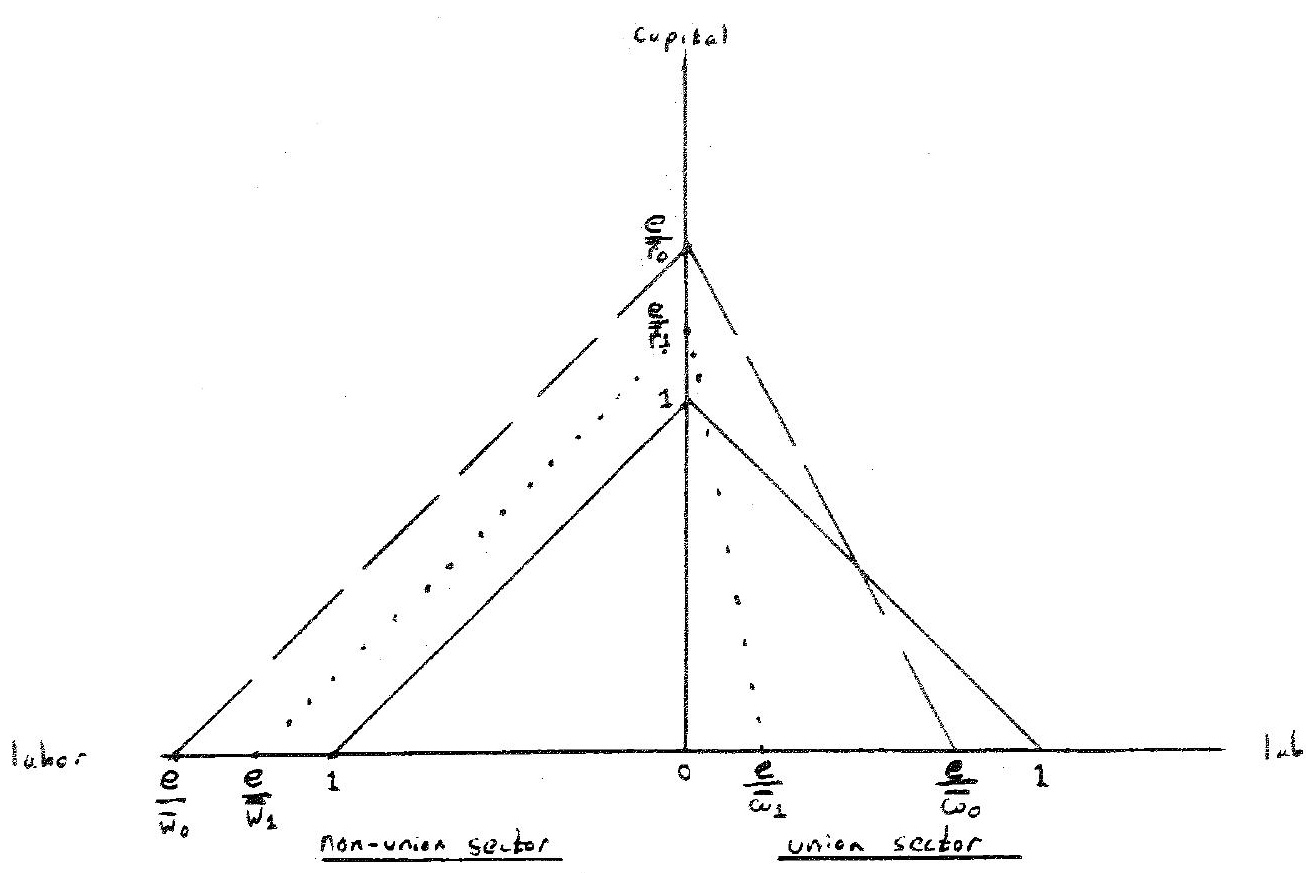

Figure lb 